\title{
DEVELOPING INNOVATIVE ENTREPRENEURSHIP ON THE BASE OF THE MODERNIZATION OF THE ECONOMICS
}

IMOMNAZAR TURSUNOV

Karshi Engineering Economics Institute, Uzbekistan

\section{ABSTRACT}

The paper recommends working out a comprehensive state program on innovative development of the Uzbekistan's economy for medium and long term perspective.

\section{JEL CLASSIFICATION \& KEYWORDS}

- $\mathrm{O} 310$ - Innovations a Innovative Activity a Innovative Cycle Mall Business — Stimulation of Innovative Entrepreneurship a Government Regulation of Innovations. INTRODUCTION

Innovative activity includes processes of development, assimilation and realization of scientific and technica innovation, combination of knowledge, efforts of scientific engineers, managers, financiers, production workers and entrepreneurs. To a large extent, innovative activity cover works starting from formation of scientific and technical ideas up to their realization in economic management practice in terms of specific products, progressing of technology, new types of raw materials, materials and energy resources. The priority of innovative development is defined by creation of conditions fir becoming principally science intensive, competitive, high technology productions. Implementing structural transformations in the economy, forming suitable investment atmosphere, modernizing the production and re-equipping it providing legally the development of the banking-financial system are especially emphasized in all the programs of our country made by the initiative of the president of our republic, Uzbekistan. The plan is then summarized in five points:

- Modernization of important parts of the economy with new technologies and equipment;

- Improving support of export-oriented companies;

- Implementing measures to decrease production costs and increase competitiveness of domestic companies on international markets;

- Implementing energy-saving measures;

- Measures to stimulate aggregate demand

Today, while determining the steady development and the prosperity of Uzbekistan, we can quote our President's speech regarding this :"the year of 2009,in its essence, was the year of experience in reforming step by step, in gradually developing strategy by the five principles of the Uzbek Module while transforming our economy from old administrative- commanding system to the market relations" So, the main purpose was generally directed towards the establishment of a legal foundation for a new economic system, formation and consolidation of statehood and elimination of old stereotypes of thinking.

The content is divided into two main parts:

- Impact of the global financial crisis on the economy of Uzbekistan and mitigated its consequences.

- Support of banking system, modernization, technical renewal and diversification of production, broad introduction of innovative technologies - a reliable way of overcoming crisis and securing by Uzbekistan of the new achievements in the world market.

\section{Main text}

One can observe all the negative sides of the world financialeconomic crisis, its features and results such as, recession, depression, and gross unemployment. However this process didn't influence much on our national economy. This proves that the Uzbek Module made by our president has a high status in order to develop our country. The government is taking all the steps while generally reforming. Perspective development of tie country is considered in the context of world tendencies and competitive models, focusing on definition of its own way of development using the elements of foreign practices. Intensive reforms required further improvement of organization of research activity, concentration of intellectual and material resources on execution of large scientific programs and innovative projects, development of mechanisms in order to get involved in the innovative activity of the real economy sector, adoption of competitive system of formation and financing of innovative scientific and technical programs arid projects.

Management of innovations en the basis of intellectual property poses a specific problem, the effective resolution of which is considered an urgent task in the period of global economic changes. In turn, the resolution of this problem allows more effective formation of the national innovative system being made up, including external economic sphere. The algorithm of national innovative system functioning includes the following stages:

- initial innovative product (IIP) represents reports on research or development works; physical models of specific inventions, as research and development products. These reports are accompanied with necessary documents proving competence of this IIP;

- representatives of innovative infrastructure select the most acceptable IIP on competitive basis;

- secondary selection is performed based in the results of the firs-stage competition;

- the selected HP are provided with conditions for development into the status of final innovative product (FIP) ready for sale in the market of business product or ready product sample and technology of its production;

- in the process of offering of FIP for sale in the market, advertising work is conducted as well as auction or other forms of trade that facilitate selling to the consumer.

All the steps concerning making Uzbekistan and other developing countries be dependent on another country aren't justified. In this period, our country accepted several laws, such as strengthening the protection of private property, forming the class of proprietors, consolidating farming actions, entrepreneurship, and first of all making convenience for small business and creating wide ranged market infrastructure.

Proceeding from the elaborately fundamental propositions laid in the basis of the privatization process and taking into consideration the already accumulated experience, we set

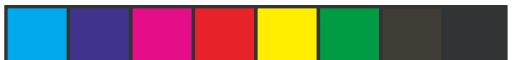


up main goals of further consolidation of the process of denationalization and privatization in the republic as following:

- to expand the scale of privatization through the involvement of medium and large enterprises of priority sectors and spheres of economy into this process;

- to convert the monopolistic production and management structures into small ones and to create the competitive market environment;

- to improve privatization facility providing for the participation of various strata of society and foreign legal and natural entities in this conversation;

- to render every kind of assistance to the converted enterprises during post- privatization period;

- to create full fledged market of securities and real estate

In the raw of reforming several economic laws, anti-crisis program including the years between 2009-2012 became effective, its main aim is to lessen the negative results of financial- economic results and to increase the stable growth of our economy, in addition it enables to raise the real income of the population.

As the president mentioned, the anti-crisis program (between 2009-2012) helped to avoid the negative side of the world crisis. In many countries of the world economic crisis has been taking place, while the GDP in our republic has increased by $8,1 \%$, Industry by $9 \%$ and investment scope by $26 \%$, in addition foreign investment by $68 \%$, and net export by 2,3 milliard dollars, the wages by $40 \%$ (ASRU 2010.)

Figure 1: Interest of entrepreneurship in GDP (percent)

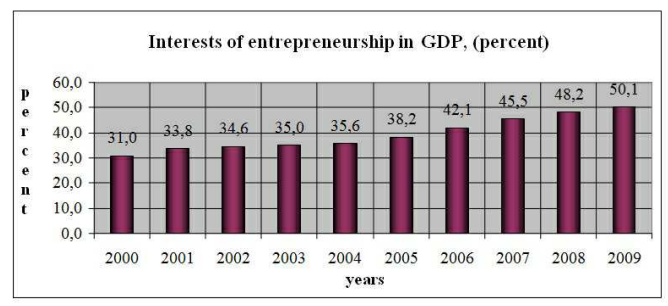

Source: http//:www. press -service.uz

As a result, the portion of small business in the GDP was over $50 \%$ in 2009 . However, this rate was $31 \%$ in 2000 (fig.-2). This result shows that small business and private entrepreneurship is being encouraged by the government Our government paid great attention to raise the employment of the labor force. For this reason, more than 940,5 thousand vacancies were created last year of which $41,7 \%$ is associated with the small business and private entrepreneurship This rate means that it increased by 4,7 $\%$ than the last year. $21 \%$ of almost all vacancies is domestic labor, $7,5 \%$ is connected with opening the new objects and about $30 \%$ is associated with enlarging the production (ISPC, 2010. http//:www.innovation.uz).

\section{Conclusion}

For the innovative developing of our national economy the role of the small business and the private entrepreneurship is inconsiderable and we see the following important directions:

1. providing the economic growth

2. increasing the prosperity and the income of the population

3. realizing the new types of goods and services

4. allocating the financial resources

\section{5. creating the new markets}

6. falling prices by cutting down the expenses

7. meeting the demand of the full range of the consumers

8. helping to create the innovative ideas

9. solving the unemployment problems and creating new vacancies

10. supporting the macro business development

Following the above mentioned principle helps to overcome the problems during the period of the economic crisis ,first of all, by encouraging the small business and the private entrepreneurship we enable to increase the level of living standards and to create too many vacancies.

While modernizing the republic, the following matters are required to solve scientifically:

1. determining the role of small business while forming the competition atmosphere

2. learning the participation of the government in controlling the small business

3. improving the budget- tax and money -credit system of the small enterprises

4. encouraging the innovation of the small business by the government

5. The problems in modernizing the economy consist of objective and subjective problems:

Objective problems:

1. innovative prices offered are very high

2. the shortage of entrepreneurship assets

3. taking too much risk

4. not having been produced all the rights of the proprietors

subjective problems:

1. there's some lack in encouraging the small business step by step by the government

2. lacking the experience workers solving the problematic situations

3. irritability of the necessary information of the small and large enterprises

There are too many problems forthcoming in addition to the economic crisis, regarding diversification and the modernization of the economy in our republic nowadays. Different areas of the organization of economic entities activities act as a form of development of innovative process. In market conditions, entities of innovative activity can develop on share basis and attract large companies, corporations, holdings and joint-stock companies. This allows for structural subdivisions to implement particular specializations at the stages of the innovative cycle due 10 their differences, size and functions. Detailed organizational and legal forms allow small forms of innovative business to survive among large ones.

The formation of technology market, production means, licenses and patents changes the function of commercial services of production enterprises and agencies, implements a rationality principle. The rationality principle says that a resource should go to those who are able to pay for it, that is, those who see $\mathrm{n}$ big perspective in using it.

\section{REFERENCES}

1. ASRU, 2010. "Uzbekistan in Figures", Agency for Statistics of Republic Uzbekistan

2. ISPC, 2010. Scientific and Practical Conference International Scientific and Practical Conference «INNOVATION-2010 Tashkent. http//:www.innovation.uz

3. Karimov I.A., 2009 "The global financial-economic crisis, ways and measures to overcome it in the conditions of Uzbekistan" Tashkent, Economics http//:www.press-service.uz 